Bull. Chem. Soc. Ethiop. 2021, 35(1), 107-118.

(C) 2021 Chemical Society of Ethiopia and The Authors

ISSN 1011-3924

DOI: https://dx.doi.org/10.4314/bcse.v35i1.9

Printed in Ethiopia

Online ISSN 1726-801X

\title{
SYNTHESIS, CHARACTERIZATION, AND PHOTOCATALYTIC EFFICIENCY OF A NEW SMART PdO OXIDE NANOMATERIALS FOR USING IN THE RECYCLING AND SUSTAINABLE WASTEWATER TREATMENT
}

\author{
Moamen S. Refat ${ }^{*}$, Hosam A Saad, Adil A. Gobouri, Mohammed Alsawat, Kaouther Belgacem, \\ Badriah M. Majrashi and Abdel Majid A. Adam \\ Department of Chemistry, College of Science, Taif University, P.O. Box 11099, Taif 21944, \\ Saudi Arabia
}

(Received August 12, 2020; Revised January 9, 2021; Accepted January 20, 2021)

\begin{abstract}
Nanostructured PdO materials with promising catalytic properties were successfully synthesized by the controlled thermal decomposition in air of three Pd(II) complexes containing Pd(II) ion, ofloxacin drug and amino acid. The $\mathrm{Pd}(\mathrm{II})$ complexes which were used as precursors were $[\mathrm{Pd}(\mathrm{OFL})(\mathrm{Gly})] \mathrm{Cl},[\mathrm{Pd}(\mathrm{OFL})(\mathrm{Ala})] \mathrm{Cl}$, and $\left[\mathrm{Pd}(\mathrm{OFL})_{2}\right] \mathrm{Cl}_{2}$, where Gly is glycine amino acid, Ala is alanine amino acid, and OFL is ofloxacin. Structural and morphological properties of the synthesized PdO materials were obtained using FTIR, XRD, SEM, and EDX techniques. The XRD results confirm the tetragonal structure of PdO. The obtained PdO materials were tested as a catalyst for the heterogeneous degradation of $\mathrm{H}_{2} \mathrm{O}_{2}$ solution. The results revealed that $\mathrm{PdO}$ could effectively degrade $\mathrm{H}_{2} \mathrm{O}_{2}$
\end{abstract}

KEY WORDS: PdO, Nanoparticles, Photocatalytic efficiency, Wastewater treatment

\section{INTRODUCTION}

Providing a clean environment that is free of any pollutants, toxic and hazardous or otherwise, is an important concern of scientists world-wide and this goal can be achieved with the help of environmentally friendly chemistry using transition metal oxides. These oxides, like $\mathrm{RuO}_{2}$, $\mathrm{Co}_{3} \mathrm{O}_{4}, \mathrm{TiO}_{2}, \mathrm{NiO}, \mathrm{PdO}, \mathrm{MnO}_{2}, \mathrm{ZnO}, \mathrm{In}_{2} \mathrm{O}_{3}, \mathrm{SnO}_{2}$, and $\mathrm{TiO}_{2}$, possess good semiconductor properties, like a significant band gap, as well as transport and optical properties that utilize transition metal oxides for different advanced photocatalytic applications [1-14]. Many pollutants and toxic and hazardous substances, like textile dyes, pesticides, and pharmaceutical drugs, were removed from environments based on photocatalytic degradation in visible light catalyzed by nanostructured transition metal oxides because the metal oxides, in nano-scale ranges, possess high surface areas and improved reactive sites [15-22]. Palladium oxide (PdO) possesses a band gap value equal to $2.2 \mathrm{eV}$ and it considered a p-type semiconductor [23, 24]. Recently, palladium metal (Pd) and its oxide (PdO) have received special attention and extensive investigation due to their unique properties as catalysts because they possess high catalytic potency at low temperatures and low volatility at high temperatures. They have wide applications [25-39] in methane combustion [25-28], carbon monoxide oxidation [29-32], catalyzing several organic conversions and reactions, like reduction reactions, hydrogenations of unsaturated olefins, and carbon-carbon cross-coupling formation [33-35], ethanol oxidation; it decomposes ethanol through decarbonylation and dehydrogenation, releasing $\mathrm{CO}$ and $\mathrm{H}$ species and environmental redemption applications when incorporating $\mathrm{Pd}$ or $\mathrm{PdO}$ with $\mathrm{TiO}_{2}$. This incorporation reduced the band gap of $\mathrm{TiO}_{2}$. This incorporating material showed extremely high photocatalytic degradation of rhodamine and methylene blue [36-39].

In this work, nanostructured PdO materials were prepared via the controlled thermal decomposition at low temperatures in air of three $\mathrm{Pd}(\mathrm{II})$ complexes containing $\mathrm{Pd}(\mathrm{II})$ ion,

*Corresponding author. E-mail: msrefat@yahoo.com; moamen@tu.edu.sa

This work is licensed under the Creative Commons Attribution 4.0 International License 
ofloxacin drug, and amino acid, and these materials were analyzed for their structural and morphological properties using the Shimadzu FT-IR spectrophotometer, XRD, SEM, and EDX techniques. The three complexes which were used as precursors were complex I $([\mathrm{Pd}(\mathrm{OFL})(\mathrm{Gly})] \mathrm{Cl})$, complex II $([\mathrm{Pd}(\mathrm{OFL})(\mathrm{Ala})] \mathrm{Cl})$, and complex III $\left(\left[\mathrm{Pd}(\mathrm{OFL})_{2}\right] \mathrm{Cl}_{2}\right)$, where Gly is glycine amino acid, Ala is alanine amino acid, and OFL is ofloxacin. The heterogeneous catalytic degradation of the prepared $\mathrm{PdO}$ materials as catalysts toward $\mathrm{H}_{2} \mathrm{O}_{2}$ was examined at room temperature in water.

\section{EXPERIMENTAL}

\section{General}

The chemicals were of analytical grades and were bought from BDH (UK) and Sigma-Aldrich (USA) chemical companies. The instruments X'Pert Philips X-ray powder diffractometer and Shimadzu FT-IR spectrophotometer were used to collect the XRD and IR spectra of the PdO materials, respectively. Their XRD spectra were scanned from $2 \theta$ of $105^{\circ}$ to $20^{\circ}$, where their IR spectra were scanned from wavenumber of $400 \mathrm{~cm}^{-1}$ to $4000 \mathrm{~cm}^{-1}$.

The SEM and EDX profiles for the PdO materials were obtained using the instruments Joel JSM-639OLV scanning electron microscope (SEM) and Noran six 200 energy dispersive X-ray (EDX) analyzer, respectively.

\section{Synthesis of the PdO materials}

Three Pd(II) complexes containing Pd(II) ion, ofloxacin drug, and amino acid (glycine or alanine) where synthesized according to the literature method [40]. These complexes are: I: $[\mathrm{Pd}(\mathrm{OFL})(\mathrm{Gly})] \mathrm{Cl}, \mathbf{I I}:[\mathrm{Pd}(\mathrm{OFL})(\mathrm{Ala})] \mathrm{Cl}$ and $\mathbf{I I I}:\left[\mathrm{Pd}(\mathrm{OFL})_{2}\right] \mathrm{Cl}_{2}$.

Complex I, $[\mathrm{Pd}(\mathrm{OFL})(\mathrm{Gly})] \mathrm{Cl}$ was prepared by adding a hot methanolic solution $(2 \mathrm{mmol}$, $40 \mathrm{~mL}, 0.722 \mathrm{~g})$ of OFL to an aqueous solution $(2 \mathrm{mmol}, 25 \mathrm{~mL}, 0.354 \mathrm{~g})$ of $\mathrm{PdCl}_{2}$ and glycine $(2 \mathrm{mmol}, 5 \mathrm{~mL}, 0.150 \mathrm{~g})$. The reaction mixtures were neutralized at $\mathrm{pH}=8-9$ and then refluxed for $6-7 \mathrm{~h}$ at $\sim 70-80{ }^{\circ} \mathrm{C}$. The solution was filtered off and left to slowly evaporate. Then, they were dried in an oven to dispose of the solvent after 6-15 h. Yellow color product was deposited and collected in a glass bottle for the chemical analyses.

Complex II, $[\mathrm{Pd}(\mathrm{OFL})(\mathrm{Ala})] \mathrm{Cl}$ was prepared by adding a hot methanolic solution $(2 \mathrm{mmol}$, $40 \mathrm{~mL}, 0.722 \mathrm{~g})$ of OFL to an aqueous solution $(2 \mathrm{mmol}, 25 \mathrm{~mL}, 0.354 \mathrm{~g})$ of $\mathrm{PdCl}_{2}$ and alanine $(2 \mathrm{mmol}, 5 \mathrm{~mL}, 0.178 \mathrm{~g})$. The reaction mixtures were neutralized at $\mathrm{pH}=8-9$ and then refluxed for 6-7 $\mathrm{h}$ at $\sim 70-80{ }^{\circ} \mathrm{C}$. The solution was filtered off and left to slowly evaporate. Then, it was dried in a drying oven to dispose of the solvent after 6-15 h. Yellowish white color product deposited and was collected a in glass bottle for the chemical analyses.

Complex III, $\left[\mathrm{Pd}(\mathrm{OFL})_{2}\right] \mathrm{Cl}_{2}$ was prepared by adding a hot methanolic solution (4 mmol, 40 $\mathrm{mL}, 1.445 \mathrm{~g})$ of OFL ligand to an aqueous solution $(2 \mathrm{mmol}, 15 \mathrm{~mL}, 0.354 \mathrm{~g})$ of $\mathrm{PdCl}_{2}$. The reaction mixture was neutralized at $\mathrm{pH}=8-9$ and then refluxed for $6-7 \mathrm{~h}$ at $\sim 70-80{ }^{\circ} \mathrm{C}$. The colored solution was filtered off and left to slowly evaporate. Afterwards, it was dried in an oven to dispose of the remaining solvent, and yellowish white color products deposited and were collected in a glass bottle for the chemical analyses.

The Gly in these complexes is glycine amino acid, Ala is alanine amino acid, and OFL is ofloxacin drug. The chemical structures of I, II and III are presented in Figure 1. Nanostructured PdO materials were prepared by the controlled thermal decomposition of I, II and III as precursors in air at temperatures of $600{ }^{\circ} \mathrm{C}$ for $3 \mathrm{~h}$ using electric furnace. The obtained PdO products were ground into fine powder $(2-3 \mathrm{~mm})$, and then characterized by the FTIR, XRD, SEM, and EDX methods. 


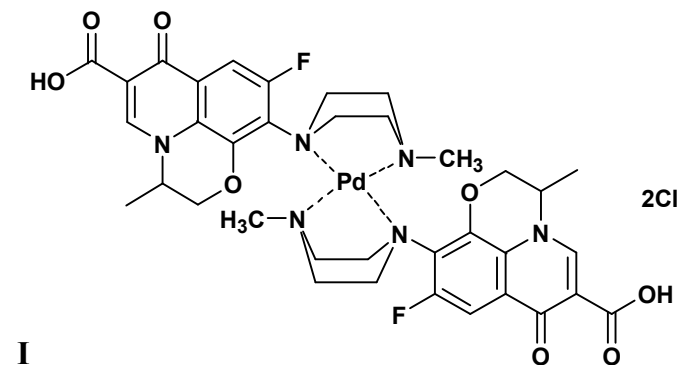<smiles></smiles>

II<smiles>CC1COc2c(N3CCN(C)[P+]4(N[C@@H](C)C(=O)O)CCC3C4)c(F)cc3c(=O)c(C(=O)O)cn1c23</smiles>

Figure 1. Chemical structures I, II and III.

\section{Catalytic experiment}

The catalytic decomposition of $\mathrm{H}_{2} \mathrm{O}_{2}$ by the synthetic $\mathrm{PdO}$ has been observed by titration of the undecomposed $\mathrm{H}_{2} \mathrm{O}_{2}$ with a standard solution of $\mathrm{KMnO}_{4}$. The $\mathrm{PdO}(0.02 \mathrm{~g})$ was mixed with 5 $\mathrm{mL}$ of $\mathrm{H}_{2} \mathrm{O}_{2}(0.01 \mathrm{~N})$ in a conical flask under magnetic stirring at room temperature. The decomposition of $\mathrm{H}_{2} \mathrm{O}_{2}$ was investigated at different times within the range of 10-50 min. Then, a $5-\mathrm{mL}$ aliquot of reaction mixture was titrated with $(0.1 \mathrm{~N}) \mathrm{KMnO}_{4}$ in the presence of an acidic $\mathrm{H}_{2} \mathrm{SO}_{4}$ solution, and the difference in consumed volumes of the $\mathrm{KMnO}_{4}$ solution before and after the catalytic decomposition was calculated. 


\section{RESULTS AND DISCUSSION}

\section{Characterization of the $\mathrm{PdO}$ materials}

The PdO materials were generated from the solid-state thermal decomposition of I, II and III at $600{ }^{\circ} \mathrm{C}$. The composition, crystallinity, and surface morphology of the obtained PdO materials were investigated using XRD, SEM, EDX and FTIR methods. Figure 2 a-c depicts the IR spectra of the prepared PdO materials. Generally, metal oxides showed IR absorption bands in the fingerprint region below $1000 \mathrm{~cm}^{-1}$ appeared from inter-atomic vibrations. The prepared PdO materials showed weak bands around $1200 \mathrm{~cm}^{-1}$ and $3000 \mathrm{~cm}^{-1}$, which may be assigned to the $\mathrm{O}-\mathrm{H}$ deformation and stretching vibrations, respectively. These bans arise from the water adsorption on the PdO surface. Bands located at $580 \mathrm{~cm}^{-1}$ and $650 \mathrm{~cm}^{-1}$ were attributed to the $\mathrm{Pd}-\mathrm{O}$ stretching vibrations [41]. Peroxo groups stretching vibrations showed that the absorption band appeared at $1365 \mathrm{~cm}^{-1}$ [42]. Figure $3 \mathrm{a}-\mathrm{c}$ represents the XRD patterns of the prepared PdO materials. These materials showed characteristic diffraction peaks at $2 \theta$ values of $71.34^{\circ}(211)$, $60.07^{\circ}(103), 54.71^{\circ}(112), 42.03^{\circ}(110), 39.78^{\circ}(101)$, and $33.57^{\circ}(002)$. These peaks can be indexed to tetragonal PdO (JCPDS Card No. 75-584) [43]. Based on the Debye-Scherrer equation, the average particle size for the PdO materials was estimated to be $\sim 40 \mathrm{~nm}$. The XRD spectra of the PdO materials showed some minor peaks, which could be due to the presence of trace of impurities presented in PdO. Figure 4 a-c presents the SEM micrographs of the prepared $\mathrm{PdO}$ materials taken with different scales from 1 to $50 \mu \mathrm{m}$ and various magnifications $(1,000 \mathrm{x}$ to $20,000 \mathrm{x}$ ). These micrographs indicate that the particles of PdO were agglomerated with nondefined structural morphology. The non-defined shaped of the particles could be due to the high surface energy of the particles and the strong tendency to form agglomerates.

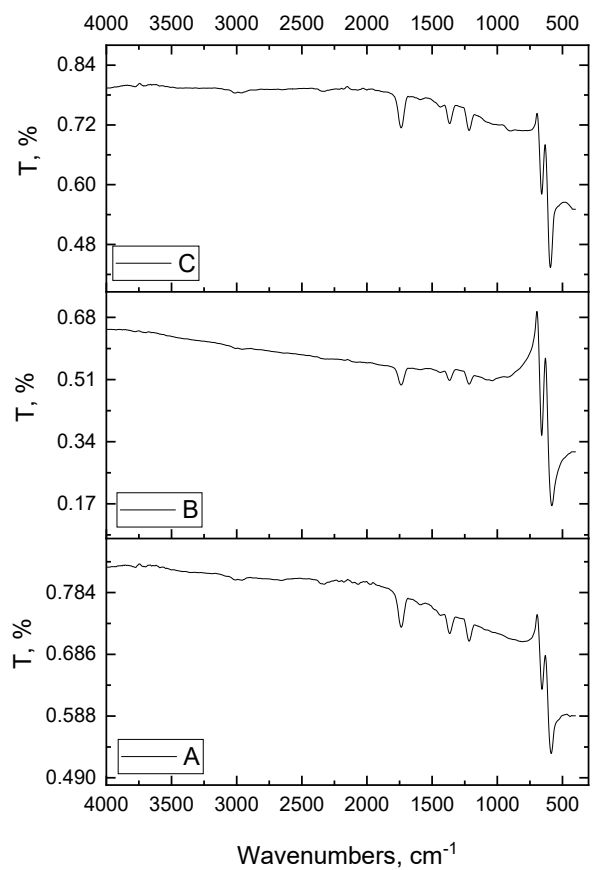

Figure 2. IR spectra of PdO generated from the calcination of I (A), II (B) and III (C) complexes.

Bull. Chem. Soc. Ethiop. 2021, 35(1) 
Synthesis, characterization, and photocatalytic efficiency of a new PdO oxide nanomaterials 111

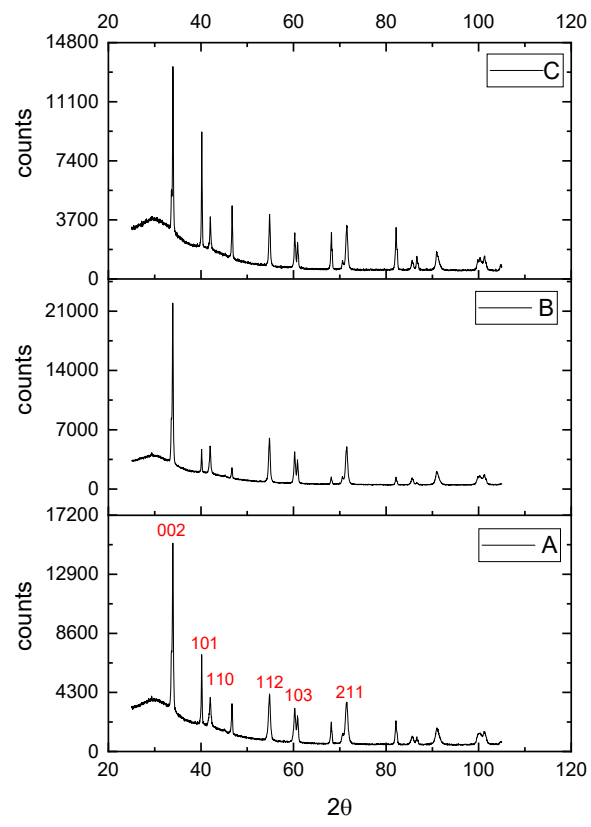

Figure 3. XRD spectra of PdO generated from the calcination of I (A), II (B) and III (C) complexes.
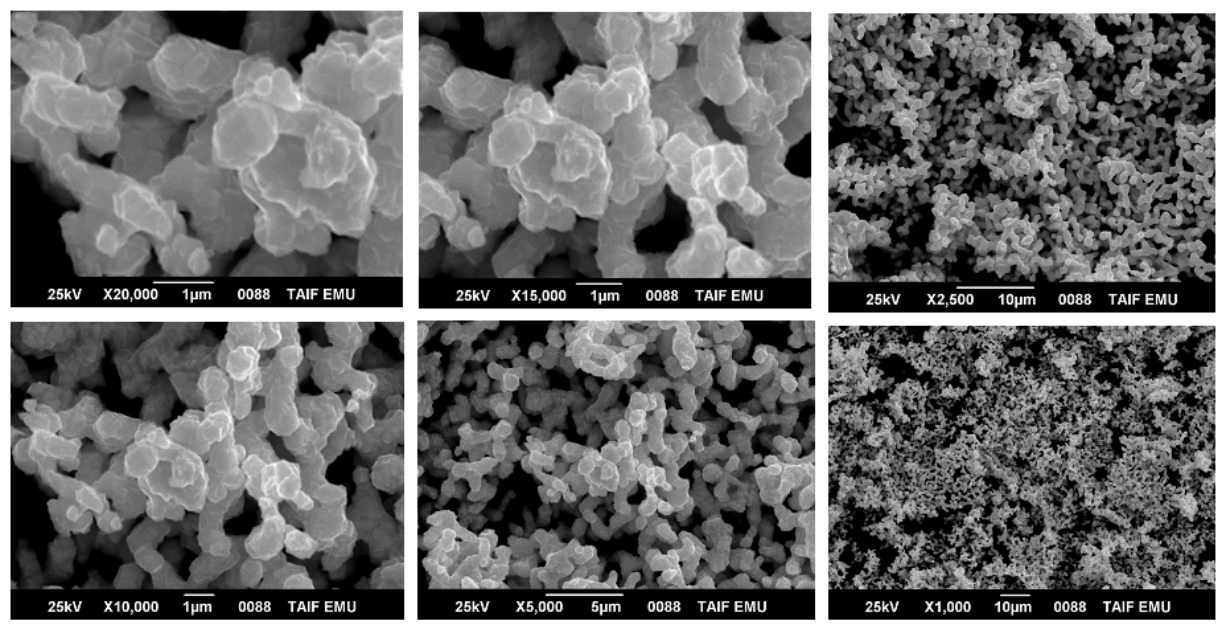

Figure 4a. SEM micrographs of $\mathrm{PdO}$ generated from the calcination of $\mathbf{I}$ at different magnifications. 

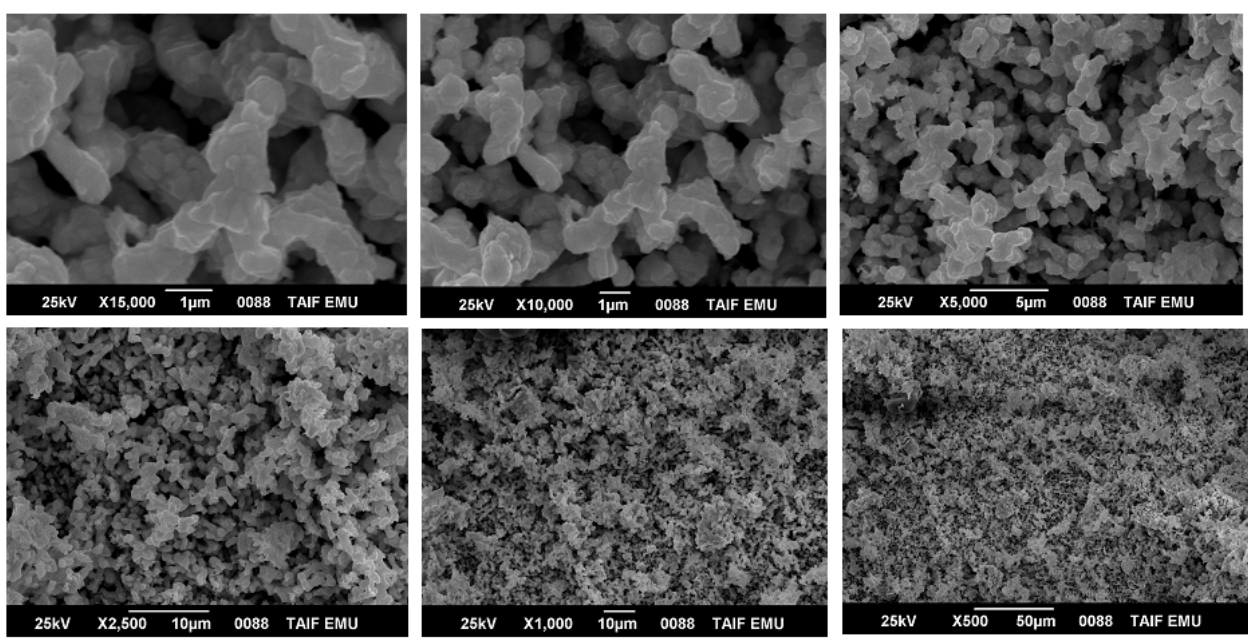

Figure 4b.SEM micrographs of $\mathrm{PdO}$ generated from the calcination of II at different magnifications.
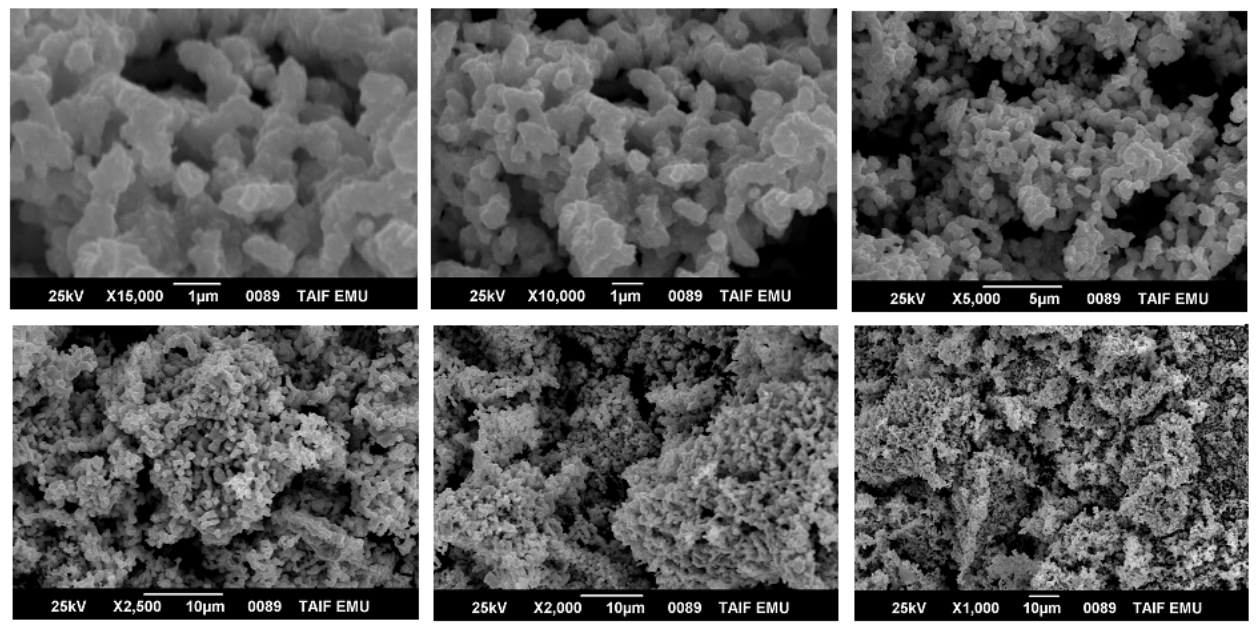

Figure 4c. SEM micrographs of $\mathrm{PdO}$ generated from the calcination of III at different magnifications. 
Synthesis, characterization, and photocatalytic efficiency of a new PdO oxide nanomaterials 113

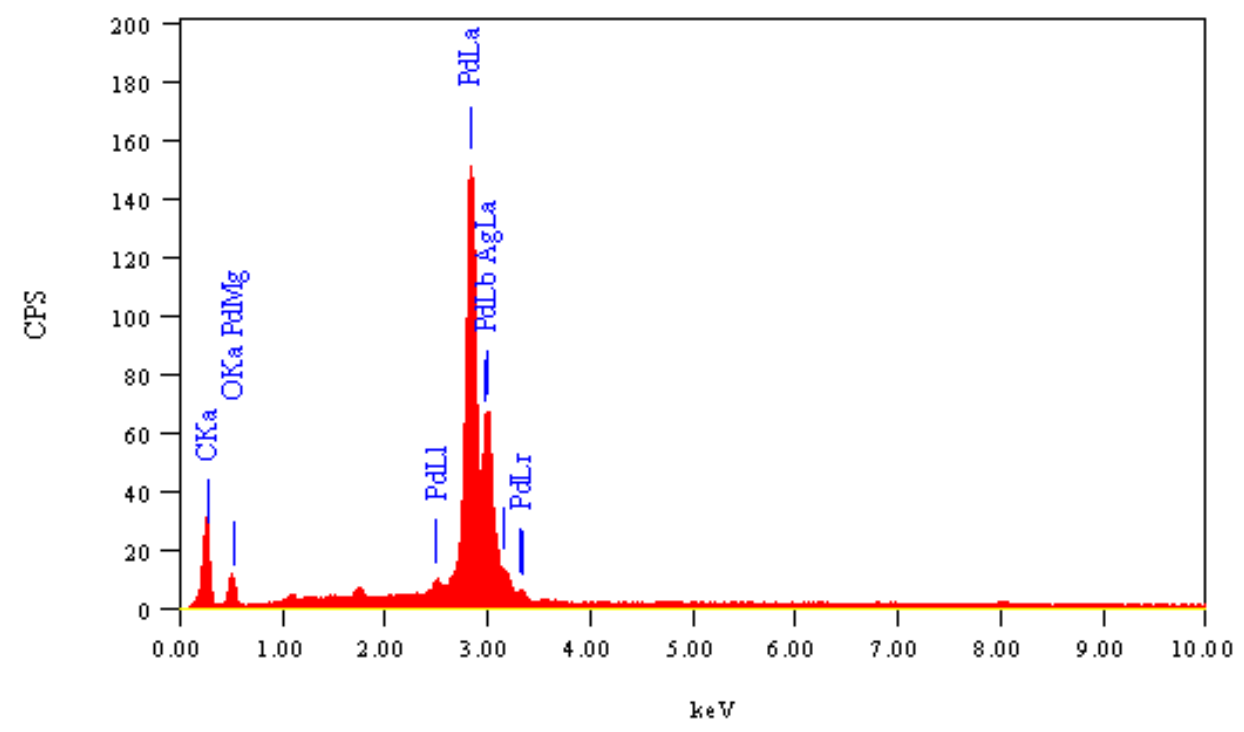

Figure 5a. EDX spectrum of PdO generated from the calcination of $\mathbf{I}$.

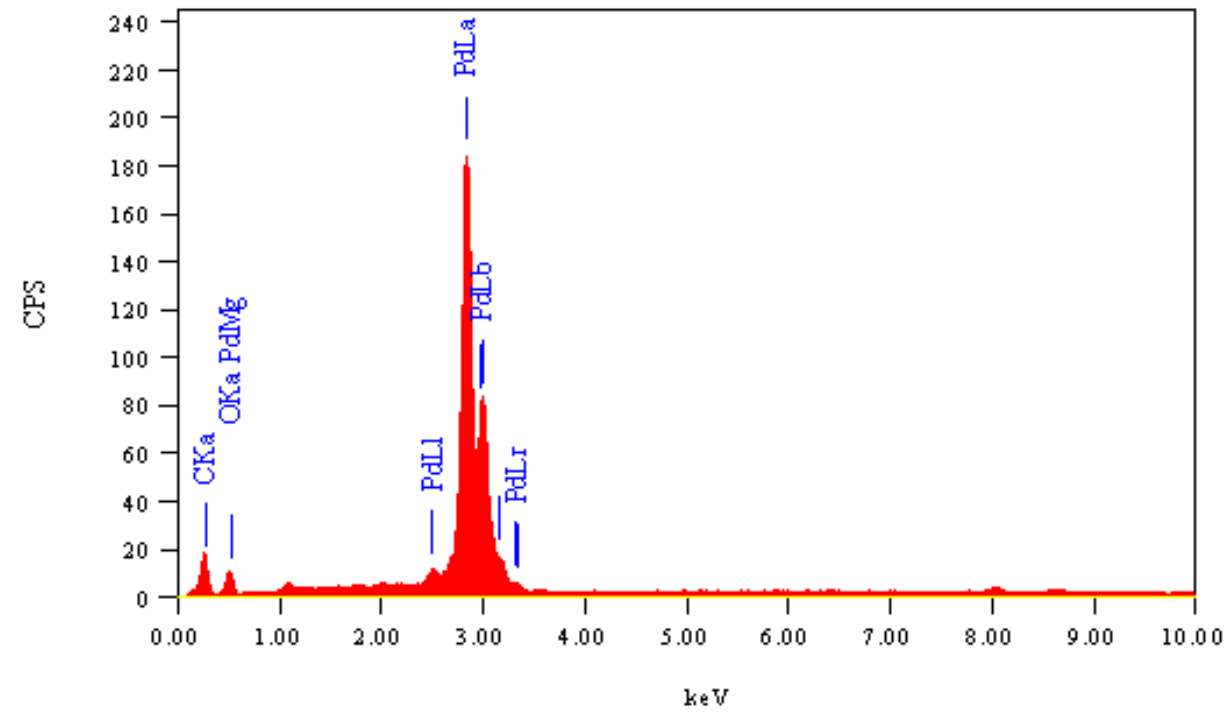

Figure 5b. EDX spectrum of PdO generated from the calcination of II. 


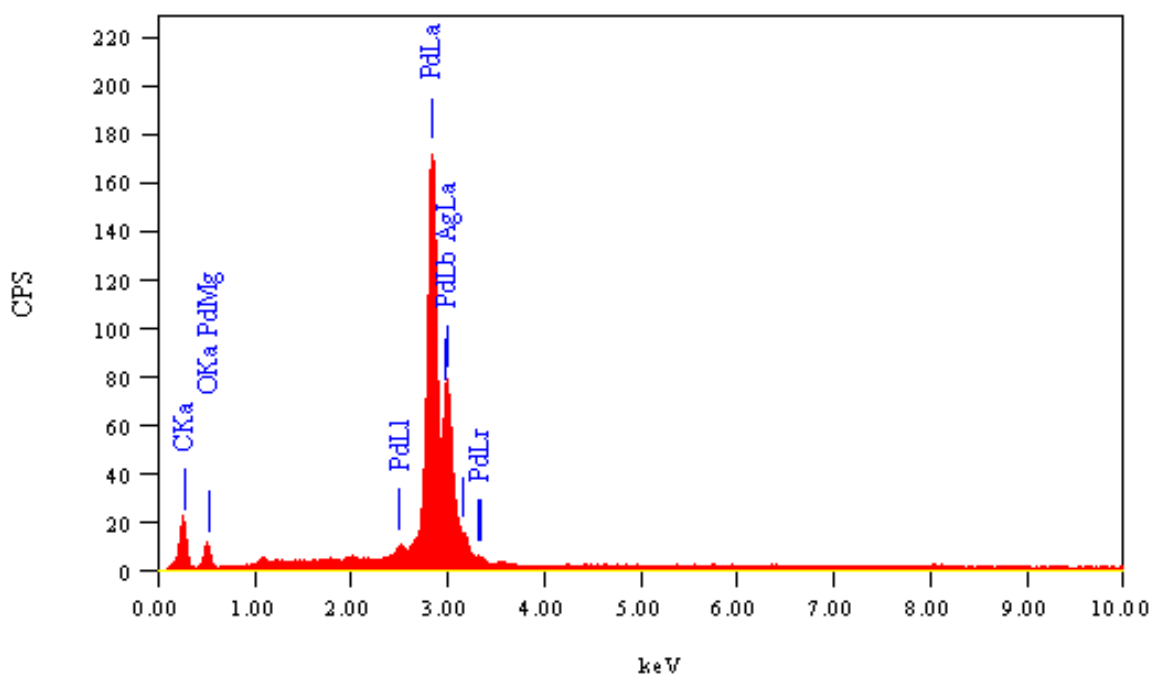

Figure 5c. EDX spectrum of PdO generated from the calcination of III.

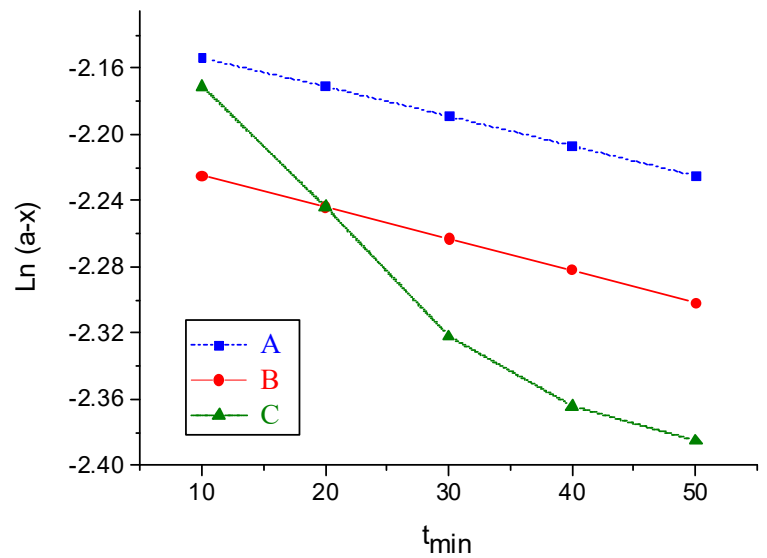

Figure 6. Effect of time (min) on the decomposition of $\mathrm{H}_{2} \mathrm{O}_{2}$ using $\mathrm{PdO}$ prepared from the calcination of A; complex I, B; complex II, and C; complex III.

Elementals analysis of the prepared PdO materials has been verified using the EDX technique, and their EDX spectra are illustrated in Figure 5 a-c. These spectra confirmed the successful preparation of the $\mathrm{PdO}$ products by the formation of the major emission energies of palladium and oxygen peaks. 
Catalytic activity of the PdO materials

Table 1 lists the catalytic activity data for the decomposition of $\mathrm{H}_{2} \mathrm{O}_{2}$ at a constant weight of $\mathrm{PdO}$ and a constant concentration of $\mathrm{H}_{2} \mathrm{O}_{2}(0.01 \mathrm{~N})$ at room temperature. Figure 6 shows that the rate of decomposition of $\mathrm{H}_{2} \mathrm{O}_{2}$ increased with time, which after 50 min were $1.8 \times 10^{-3}<2.0 \times 10^{-3}$ $<7.8 \times 10^{-3}$ for the synthesized PdO products from the thermal decomposition of I, II and III, respectively. The catalytic decomposition of $\mathrm{H}_{2} \mathrm{O}_{2}$ tends to be associated with an intermediate radical species, which can bind to the surfaces where $\mathrm{H}_{2} \mathrm{O}_{2}$ undergoes decomposition [44, 45]. The degree of decomposition of $\mathrm{H}_{2} \mathrm{O}_{2}$ showed inverse dependent on the surface area, pore volume and mean pore dimensions. The chemical nature of the surface, rather than the porosity characterizations, was the principal factor in enhancing the disproportionation of $\mathrm{H}_{2} \mathrm{O}_{2}$ on the prepared $\mathrm{PdO}$ oxides.

Table 1. Catalytic activity data of the PdO synthesized from the calcination of I, II and III.

\begin{tabular}{|c|c|c|c|c|c|}
\hline \multicolumn{6}{|c|}{ PdO synthesized from calcination of $\mathbf{I}$} \\
\hline \multirow{2}{*}{ Results } & \multicolumn{5}{|l|}{$t_{\min }$} \\
\hline & 10 & 20 & 30 & 40 & 50 \\
\hline $\mathrm{V}_{(\mathrm{KMnO4)}}$ & 5.8 & 5.7 & 5.6 & 5.5 & 5.4 \\
\hline $\mathrm{N}_{(\mathrm{H} 2 \mathrm{O} 2)} \mathrm{a}-x$ & 0.116 & 0.114 & 0.112 & 0.110 & 0.108 \\
\hline $\operatorname{Ln}(a-x)$ & -2.154 & -2.171 & -2.189 & -2.207 & -2.225 \\
\hline $\mathrm{K}$ & \multicolumn{5}{|l|}{$1.8 \times 10^{-3}$} \\
\hline \multicolumn{6}{|c|}{ PdO synthesized from calcination of II } \\
\hline $\mathrm{V}_{(\mathrm{KMnO} 4)}$ & 5.4 & 5.3 & 5.2 & 5.1 & 5.0 \\
\hline $\mathrm{N}_{(\mathrm{H} 2 \mathrm{O} 2)} \mathrm{a}-x$ & 0.108 & 0.106 & 0.104 & 0.102 & 0.100 \\
\hline $\operatorname{Ln}(a-x)$ & -2.225 & -2.244 & -2.263 & -2.282 & -2.302 \\
\hline $\mathrm{K}$ & \multicolumn{5}{|l|}{$2.0 \times 10^{-3}$} \\
\hline \multicolumn{6}{|c|}{ PdO synthesized from calcination of III } \\
\hline $\mathrm{V}_{(\mathrm{KMnO} 4)}$ & 5.7 & 5.3 & 4.9 & 4.7 & 4.6 \\
\hline $\mathrm{N}_{(\mathrm{H} 2 \mathrm{O} 2)} \mathrm{a}-x$ & 0.114 & 0.106 & 0.098 & 0.094 & 0.092 \\
\hline $\operatorname{Ln}(a-x)$ & -2.171 & -2.244 & -2.322 & -2.364 & -2.385 \\
\hline $\mathrm{K}$ & \multicolumn{5}{|l|}{$7.8 \times 10^{-3}$} \\
\hline
\end{tabular}

$* \mathrm{~K}\left(\mathrm{~min}^{-1}\right)=$ rate constant of the $\mathrm{H}_{2} \mathrm{O}_{2}$ decomposition.

\section{CONCLUSION}

In this work, nanostructured $\mathrm{PdO}$ oxide nanomaterials were synthesized by the calcination of three Pd(II) complexes. These complexes contained ofloxacin drug, amino acid (alanine or glycine), and $\mathrm{Pd}(\mathrm{II})$ ions. The structure and morphology of the synthesized PdO nanomaterials were characterized using FTIR, XRD, SEM, and EDX techniques. The PdO nano oxides were tested as a catalyst for the heterogeneous catalytic activity degradation of $\mathrm{H}_{2} \mathrm{O}_{2}$ solution at room temperature.

\section{ACKNOWLEDGEMENT}

The authors extend their appreciation to the Deputyship for Research \& Innovation, Ministry of Education in Saudi Arabia for funding this research work through the project number 127-4411. 


\section{REFERENCES}

1. Garey, K.W.; Amsden, G.W. Trovafloxacin: An overview. Pharmacotherapy 1999, 19, 2134.

2. Fitton, A. The quinolones. Clin Pharmacokinet. 1992, 22 (suppl 1), 1-11.

3. Stein, G.E. Pharmacokinetics and pharmacodynamics of newer fluoroquinolones. Clin Infect. Dis. 1996, 23 (suppl 1), S19-S24.

4. Norrby, S.R.; Lietman, P.S. Safety and tolerability of fluoroquinolones. Drugs 1993, 45 (suppl 3), 59-64.

5. King, D.E.; Malone, R.; Lilley, S.H. New classification and update on the quinolone antibiotics. Am. Fam. Physician. 1. 2000, 61, 2741-2748.

6. Ruiz, M.; Ortiz, R.; Perello, L. Ni(II) and Zn(II) complexes with cinoxacin. Synthesis and characterization of $\mathrm{M}(\mathrm{Cx}) 2(\mathrm{DMSO}) n(\mathrm{H} 2 \mathrm{O}) m(n=0,2 ; m=2,4)$. Crystal structures of [M(Cx)2(DMSO)2]·4H2O (M = Ni(II), Zn(II)). Inorg. Chim. Acta 1993, 211, 133-139.

7. Ruiz, M.; Ortiz, R.; Perello, L.; Garcia-Granda, S.; Diaz, M.R. Synthesis and characterization of $\mathrm{Cd}(\mathrm{II})$ complexes of cinoxacin. Crystal structure of a dicadmium complex containing two monoatomic-bridging carboxylate oxygen atoms. Inorg. Chim. Acta. 1994, 217, 149-154.

8. Huang, G.-M.; Tsai, T.-C.; Huang, C.-W.; Kumar, N.; Tseng, T.-Y.; Wu, W.-W. Dynamic observation of reversible lithium storage phenomena in hybrid supercapacitor devices. Nano Energy, 2017, 41, 494-500.

9. Ren, H.; Yu, R.; Qi, J.; Zhang, L.; Jin, Q.; Wang, D. Hollow Multishelled Heterostructured Anatase/TiO2(B) with Superior Rate Capability and Cycling Performance. Adv. Mater. 2019, 31(10), 1805754.

10. Li, Y.F.; Shi, Y.H.; Wang, S.G.; Liu, J.H.; Lin, J.; Xia, Y.; Wu, X.L.; Fan, C.Y. Carbon/Binder-Free NiO@NiO/NF with In Situ Formed Interlayer for High-Areal-Capacity Lithium Storage. Adv. Eng. Mater. 2019, 1803690.

11. Bencheikh, Y.; Harnois, M.; Jijie, R.; Addad, A.; Roussel, P.; Szuneris, S.; Hadjersi, T.; Boukherroub, R. High performance silicon nanowires/ruthenium nanoparticles microsupercapacitors. Elelctrochim. Acta. 2019, 311, 150-159.

12. Zhang, Y.; Park, S.-J. Incorporation of $\mathrm{RuO} 2$ into charcoal-derived carbon with controllable microporosity by $\mathrm{CO} 2$ activation for high-performance supercapacitor. Carbon, 2017, 122 , 287-297.

13. Fu, Y.; Gao, X.; Zha, D.; Zhu, J.; Ouyang, X.; Wang, X. Yolk-shell-structured $\mathrm{MnO} 2$ microspheres with oxygen vacancies for high-performance supercapacitors. J. Mater. Chem. 2018, 6, 1601-1611.

14. Asim, S.; Javed, M.S.; Hussain, S.; Rana, M.; Iram, F.; Lv, D.; Hashim, M.; Saleem, M.; Khalid, M.; Jawaria, R.; Ullah, Z.; Gull, N. RuO2 nanorods decorated CNTs grown carbon cloth as a free-standing electrode for supercapacitor and lithium ion batteries. Elelctrochim. Acta. 2019, 326, 135009. https://doi.org/10.1016/j.electacta.2019.135009

15. Ruiz, M.; Perello, L.; Ortiz, R.; Castineiras, A.; Maichle-Mossmer, C.; Canton, E. Synthesis, characterization, and crystal structure of [Cu(cinoxacinate)2] $\cdot 2 \mathrm{H} 2 \mathrm{O}$ complex: A squareplanar $\mathrm{CuO} 4$ chromophore. Antibacterial studies. J. Inorg. Biochem. 1995, 59, 801-810.

16. Ruiz, M.; Ortiz, R.; Perello, L.; Latorre, J.; Server-Carrio, J. Potentiometric and spectroscopic studies of transition-metal ions complexes with a quinolone derivative (cinoxacin). Crystal structures of new $\mathrm{Cu}(\mathrm{II})$ and $\mathrm{Ni}(\mathrm{II})$ cinoxacin complexes. J. Inorg. Biochem. 1997, 65, 87-96.

17. Ruiz, M.; Perello, L.; Server-Carrio, J.; Ortiz, R.; Garcia-Granda, S.; Diaz, M.R.; Canton, E. Cinoxacin complexes with divalent metal ions. Spectroscopic characterization. Crystal structure of a new dinuclear Cd(II) complex having two chelate-bridging carboxylate groups. Antibacterial studies. J. Inorg. Biochem. 1998, 69, 231-239. 
18. Macias, B.; Villa, M.V.; Rubio, I.; Castineiras, A.; Borras, J. Synthesis, characterization, and crystal structure of $[\mathrm{Cu}$ (cinoxacinate)2] - $2 \mathrm{H} 2 \mathrm{O}$ complex: A square-planar $\mathrm{CuO} 4$ chromophore. Antibacterial studies. J. Inorg. Biochem. 1995, 59, 801-810.

19. Li, Y.H.; Tang, Y.Z.; Huang, X.F.; Xiong, R.G. The Crystal Structure of a Gatifloxacin Complex and its Fluorescent Property. Z. Anorg. Allg. Chem. 2005, 631, 639-641.

20. Psomas, G.; Tarushi, A.; Efthimiadou, E.K.; Sanakis, Y.; Raptopoulou, C.P.; Katsaros, N. Synthesis, structure and biological activity of copper(II) complexes with oxolinic acid. $J$. Inorg. Biochem. 2006, 100, 1764-1773.

21. Sunberg, R.J.; Martin, R.B. Interactions of histidine and other imidazole derivatives with transition metal ions in chemical and biological systems. Chem. Rev. 1974, 74, 471-517.

22. Nagaraja, R.; Nagappa, B.; Girija, C.R.; Nagabhushana, B.M. Synthesis and Characterization of Nanocrystalline $\mathrm{MgO}$ Powder and its Application in the Treatment of Pharmaceutical Effluent. J. Nanotech. Appl. 2011, 11, 28.

23. Cheng, I.; Wang, J.; Tsai, C.; Chen, Y.; Pan, F. Correlation of surface processes with characteristic sensing responses of PdO thin films to ethanol. Appl. Surf. Sci. 2019, 473, 589-596.

24. Huang, C.-J.; Pan, F.-M.; Chen, H.-Y.; Chang, L. Growth and photoresponse study of PdO nanoflakes reactive-sputter deposited on SiO2. J. Appl. Phys. 2010, 108, 053105.

25. Veziroglu, S.; Hwang, J.; Drewes, J.; Barg, I.; Shondo, J.; Strunskus, T.; Polonskyi, O.; Faupel, F.; Aktas, O.C. PdO nanoparticles decorated $\mathrm{TiO} 2$ film with enhanced photocatalytic and self-cleaning properties. Mater. Today Chem. 2020, 16, 100251. https://doi.org/10.1016/j.mtchem.2020.100251

26. Hadi, A.; Yaacob, I.I. Synthesis of $\mathrm{PdO} / \mathrm{CeO} 2$ mixed oxides catalyst for automotive exhaust emissions control. Catal. Today 2004, 96, 165-170.

27. Khojasteh, H.; Salavati-Niasari, M.; Abbasi, A.; Azizi, F.; Enhessari, M. Synthesis, characterization and photocatalytic activity of $\mathrm{PdO} / \mathrm{TiO} 2$ and $\mathrm{Pd} / \mathrm{TiO} 2$ nanocomposites. $J$. Mater. Sci. Mater. Electron. 2016, 27, 1261-1269.

28. Zhou, W.; Guan, Y.; Wang, D.; Zhang, X.; Liu, D.; Jiang, H.; Wang, J.; Liu, X.; Liu, H. $\mathrm{PdO} / \mathrm{TiO} 2$ and $\mathrm{Pd} / \mathrm{TiO} 2$ Heterostructured Nanobelts with Enhanced Photocatalytic Activity. Chem. Asian J. 2014, 9, 1648-1654.

29. Ismail, A.A. Mesoporous $\mathrm{PdO}-\mathrm{TiO} 2$ nanocomposites with enhanced photocatalytic activity. Appl. Catal. B Environ. 2012, 117-118, 67-72.

30. Huang, C.-J.; Pan, F.-M.; Chang, I.-C. Enhanced photocatalytic decomposition of methylene blue by the heterostructure of $\mathrm{PdO}$ nanoflakes and TiO2 nanoparticles. Appl. Surf. Sci. 2012, 263, 345-351.

31. Letichevsky, S.; Zonetti, P.C.; Reis, P.P.P.; Celnik, J.; Rabello, C.R.K.; Gaspar, A.B.; Appel, L.G. The role of $m-\mathrm{ZrO} 2$ in the selective oxidation of ethanol to acetic acid employing $\mathrm{PdO} / m-\mathrm{ZrO} 2$. J. Mol. Catal. A Chem. 2015, 410, 177-183.

32. Reis, P.P.P.; Zonetti, P.C.; Passos, F.B.; Appel, L.G. Acetic Acid Synthesis from Ethanol: Describing the Synergy Between PdO and m-ZrO2. Catal. Lett. 2017, 147, 821-827.

33. Jürgensen, A.; Heutz, N.; Raschke, H.; Merz, K.; Hergenröder, R. Behavior of Supported Palladium Oxide Nanoparticles under Reaction Conditions, Studied with near Ambient Pressure XPS. Anal. Chem. 2015, 87, 7848-7856.

34. Dogra, V.; Kaur, G.; Kumar, R.; Kumar, S. Toxicity assessment of palladium oxide nanoparticles derived from metallosurfactants using multi assay techniques in Allium sativum. Colloids Surf. B. 2020, 187, 110752.

35. Das, P.; Linert, W. Schiff base-derived homogeneous and heterogeneous palladium catalysts for the Suzuki-Miyaura reaction. Coord. Chem. Rev. 2016, 311, 1-23.

36. Saldan, I.; Semenyuk, Y.; Marchuk, I.; Reshetnyak, O. Chemical synthesis and application of palladium nanoparticles. J. Mater. Sci. 2015, 50, 2337-2354. 
37. Sheldon, R.A. Recent advances in green catalytic oxidations of alcohols in aqueous media. Catal. Today. 2015, 247, 4-13.

38. Aditya, T.; Pal, A.; Pal, T. Nitroarene reduction: a trusted model reaction to test nanoparticle catalysts. Chem. Commun. 2015, 51, 9410-9431.

39. Pramanik, S.; Das, M.R.; Das, D.; Das, P. Sustainable Redox Chemistry Route to Multifaceted Fe-Pd Heteronanostructure: Delving into the Synergistic Influence in Catalysis. ChemistrySelect. 2017, 2, 4577-4585.

40. Naglah, A.M.; Al-Omar, M.A.; Almehizia, A.A.; AlKahtani, H.M.; Bhat, M.A.; AlShakliah, N.S.; Belgacem, K.; Majrashi, B.M. Refat, M.S.; Adam, A.M.A. Synthesis, thermogravimetric, and spectroscopic characterizations of three palladium metal(II) ofloxacin drug and amino acids mixed ligand complexes as advanced antimicrobial materials. J Mol. Struct. 2021, 1225, article No. 129102 pages 1-10.

41. Rao, C.N.R. Chemical Applications of Infrared spectroscopy, Academic Press, New York, and London, 1963.

42. Wang, Y.; Herron, N. Nanometer-sized semiconductor clusters: materials synthesis, quantum size effects, and photophysical properties. J. Phys. Chem. 1991, 95, 525-532.

43. He, H.; Gao, C. A General Strategy for the Preparation of Carbon Nanotubes and Graphene Oxide Decorated with PdO Nanoparticles in Water. Molecules. 2010, 15, 4679-4694.

44. Lousada, C.M.; Jonsson, M. Kinetics, Mechanism, and Activation Energy of $\mathrm{H} 2 \mathrm{O} 2$ Decomposition on the Surface of $\mathrm{ZrO}_{2}$. J. Phys. Chem. 2010, 114, 11202-11208.

45. Zigah, D.; Lopez, J.R.; Bard, A. Quantification of photoelectrogenerated hydroxyl radical on $\mathrm{TiO}_{2}$ by surface interrogation scanning electrochemical microscopy. J. Phys. Chem. 2012, $14,12764-12772$. 